Published in final edited form as:

Curr Med Chem. 2015 January 13; 22(9): 1136-1146.

\title{
Recent Advances on Small-Molecule Survivin Inhibitors
}

\author{
Min Xiao and Wei Li ${ }^{*}$ \\ Department of Pharmaceutical Sciences, University of Tennessee Health Science Center, \\ Memphis, Tennessee 38163, United States
}

\begin{abstract}
Survivin, a member of the inhibitor of apoptosis proteins family, is highly expressed in most human neoplasms, but its expression is very low or undetectable in terminally differentiated normal tissues. Survivin has been shown to inhibit cancer cell apoptosis and promote cell proliferation. The overexpression of survivin closely correlates with tumor progression and drug resistance. Because of its key role in tumor formation and maintenance, survivin is considered as an ideal target for anticancer treatment. However, the development of small-molecule survivin inhibitors has been challenging due to the requirement to disrupt the protein-protein interactions. Currently only a limited number of survivin inhibitors have been developed in recent years, and most of these inhibitors reduce survivin levels by interacting with other biomolecules instead of directly interacting with survivin protein. Despite these challenges, developing potent and selective small-molecule survivin inhibitors will be important in both basic science to better understand survivin biology and in translational research to develop potentially more effective, broadspectrum anticancer agents. In this review, the functions of survivin and its role in cancer are summarized. Recent developments, challenges, and future direction of small-molecule survivin inhibitors are also discussed in detail.
\end{abstract}

\section{Keywords}

BIRC5 inhibitor; inhibitor of apoptosis proteins; protein-protein interaction inhibitor; smallmolecule anticancer agent; survivin and cancer; survivin inhibitor

\section{Introduction}

Survivin, an anti-apoptotic protein, was discovered by Grazia Ambrosini and Dario C. Altieri in 1997[1]. Survivin is a member of the inhibitor of apoptosis proteins (IAP) family of which there are eight members: NAIP (NLR family, apoptosis inhibitory protein), c-IAP1, c-IAP2, XIAP (X-linked inhibitor of apoptosis), livin, ILP-2, apollon, and survivin (Figure 1) [2-5]. Each member contains at least a single baculoviral IAP repeat (BIR) domain at the $\mathrm{N}$-terminus region [2]. Survivin is encoded by baculoviral inhibitor of apoptosis repeat-

\footnotetext{
"To whom correspondence should be addressed. Wei Li, Ph.D., Address: Room 327B, 847 Monroe Ave, Memphis, TN 38163 , Telephone: (901)448-7532. Fax: (901)448-6828. wli@uthsc.edu.

Conflict of Interest

This work was partially supported by NIH grants R01CA148706, 1S10OD010678-01, 1S10RR026377-01 to Wei Li. The content is solely the responsibility of the authors and does not necessarily represent the official views of the National Institutes of Health.
} 
containing 5 (BIRC5), so it is also called BIRC5. Compared with other IAPs that contain multiple domains, survivin is structurally unique because it contains only one single BIR domain. It is the smallest member of the IAP family, has a molecule weight of $16.5 \mathrm{kDa}$, and contains 142 amino acid residues [6, 7]. Unlike other IAPs that are expressed in both cancerous and normal cells, survivin is expressed only in the vast majority of neoplasms but not in most normal differentiated tissues [8-11]. Survivin also contributes to tumor formation and maintenance because of its functional properties [12, 13]. Therefore, targeting survivin represents a very attractive strategy in cancer drug discovery. However, due to the requirement of efficiently disrupting protein-protein interactions which typically have large interface areas, the development of small-molecule survivin inhibitors has been very challenging. Thus the number of currently available survivin inhibitors is small. In addition, most of these inhibitors target other biomolecules and ultimately reduce the level of survivin, rather than directly interact with survivin protein itself. Despite these challenges and limitations, developing new potent and selective small-molecule survivin inhibitors will be important in both basic science and translational research to develop them into potentially effective, broad-spectrum therapeutic agents. In this review, we first describe the functions of survivin, its role in cancer progression and potential therapy. Then we focus on recently developed small-molecule survivin inhibitors. Challenges for developing survivin inhibitors and future direction will also be covered.

\section{Functions of survivin}

The main established functions of survivin are the regulation of cell mitosis and the inhibition of apoptosis as illustrated in Figure 2. Survivin plays an essential role in cell mitosis [14], during which survivin regulates cell division through a multiprotein complex called chromosomal passenger complex (CPC) as shown in Figure 2. In this complex, survivin is associated with other regulators of cytokinesis including aurora kinase B, INCENP, and borealin [15-17]. CPC is essential for accurate chromosome segregation and cytokinesis. Survivin and its molecular partners in the CPC fundamentally control genetic stability of cells [18]. Survivin has also been shown to be associated with regulating microtubule dynamics [19-21]. Survivin stabilizes the microtubules, thereby contributing to the formation of the bipolar spindle [21].

Similar to other members in the IAP family, one main function of survivin is the inhibition of apoptosis as shown in Figure 2 [22-25]. Although it has been confirmed that survivin inhibits apoptosis, the exact mechanism of inhibition is still under debate over two major theories. One theory is that survivin directly binds to caspases and subsequently inhibits apoptosis. The interaction between survivin and the effector caspases has been reported by several groups $[22,23]$. The second theory is that survivin inhibits caspase activity through indirect mechanisms to inhibit apoptosis [26-28]. One example proposes that survivin binds to XIAP to form a complex that inhibits the activation of caspase-9 [26, 27]. In another example, a survivin-hepatitis B X-interacting protein (HBXIP) complex binds to procaspase-9 to suppress apoptosis [28]. 


\section{Roles of survivin in cancer}

Both the functions of promoting cell proliferation and inhibiting apoptosis contribute to the formation and maintenance of tumors. Because the expression level of survivin in normal cells and malignant cells is largely different, survivin can be used as a tumor biomarker [2931]. Many studies have confirmed that survivin is overexpressed in a variety of cancers (e.g., lung, breast, pancreatic, and melanoma) [32-35]. Survivin has also been shown to be responsible for multiple types of drug resistance [36-39]. For example, it has been reported that taxol-treated HeLa cells show an increased level of survivin expression, which provides a cell survival pathway to counteract taxol-induced apoptosis [19]. Overexpression of survivin has also been reported in prostate cancer and thyroid cancer cells that are resistant to cisplatin treatment $[40,41]$. Because survivin is crucial in the process of carcinogenesis, knockout of survivin impedes the development of cancer. A recent study showed that loss of survivin in the prostate epithelium inhibited the progression of prostatic premalignant lesions to adenocarcinoma in the Pten-deletion mouse model [42]. The study confirms the role of survivin in cancer progression.

\section{Targeting survivin for cancer treatment}

Survivin has been proposed as an attractive target for selective cancer treatment because of its unique attributes [43]. The following features are some reasons that targeting survivin is a good strategy. First, the expression of survivin is typically very high in tumor cells but very low or even undetectable in normal adult tissues[8]. This feature is highly significant, because it provides selectivity, a major problem for current cancer drug development. Second, the functions of survivin contribute to the formation and maintenance of tumors [44], so targeting survivin will be very effective for treating cancer. Furthermore, survivin has been shown to be associated with resistance to multiple types of cancer therapies [4547]. Targeting survivin can help overcome the multidrug resistance which is one of the major reasons many therapeutic agents fail in clinic. However, there are still significant challenges associated with using survivin as a drug target. Small-molecule survivin inhibitors have to disrupt the protein-protein interaction between survivin and other proteins, which could be difficult because most interfaces in protein-protein interactions (PPIs) are not well suitable for effective small molecule binding [48]. Despite the difficulties for small molecules to disrupt protein-protein interactions, there are some successful PPI inhibitors [49], including tirofiban (targeting the integrins) and maraviroc (targeting CCR5-gp120 interactions) which are already on the market [50,51]. Those successes are probably attributed to the fact that most PPIs have "hot spots" which are small parts of the interface that are essential for high-affinity binding [52]. Small-molecule PPI inhibitors can either interact with those hot spots or bind to allosteric sites to cause conformational change that will prevent protein-ligand binding, which will result in the desired disruption of proteinprotein interactions. In the case of developing small-molecule survivin inhibitors, the AlaVal-Pro-Ile (AVPI) peptide binding region has been proposed as a hot spot for small molecule inhibition [53, 54]. Therefore, targeting survivin is tractable for cancer treatment in spite of the challenges. Many survivin inhibitors have been reported in the literature. These survivin inhibitors are mainly composed of six categories: antisense oligonucleotides, dominant-negative mutant, ribozymes, small interfering RNAs, cancer vaccine, and small- 
molecule inhibitors. Several reviews have been published covering all kinds of survivin inhibitors in general $[6,55,56]$, but no review specifically focuses on small-molecule survivin inhibitors, which is the focus of this review. As we discussed earlier, most existing survivin inhibitors do not directly bind and interact with survivin protein itself, instead, they usually target other biomolecules and ultimately reduce survivin expression. Figure 2 shows three representative examples. The first example is YM155 which inhibits survivin by inhibiting survivin gene promoter on the transcriptional level [57]. The second example is represented by cyclin-dependent kinase (CDK) inhibitors. For example, the CDK inhibitor flavopiridol inhibits survivin phosphorylation on Thr34 which leads to progressive loss of survivin expression [58]. The last example shown in Figure 2 for indirect targeting survivin are Hsp90 inhibitors which disrupt the interaction between survivin and Hsp90, destabilize survivin protein and ultimately lead to survivin degradation. In the following sections, we will discuss each reported small-molecule survivin inhibitor (arranged alphabetically) in detail.

\section{Existing small-molecule survivin inhibitors}

AICAR (1)

The nonpeptidic, small-molecule 5-aminoimidazole-4-carboxamide-1-b-D-ribofuranoside (AICAR) as a structurally novel inhibitor of Hsp90 was developed through a combined structure- and dynamics-based computational design [59]. AICAR mimics the binding and functional properties of the peptidic antagonist of the survivin-Hsp90 complex, shepherdin. The AICAR/Hsp90 interaction studies revealed that AICAR is involved in direct contacts with Asp93 of Hsp90 through the two hydroxyl groups on position 3 and 5 of the ribose ring, suggesting that replacement of these residues with other polar groups may strengthen the interaction. This is also true for the polar substituents on the imidazole ring. AICAR has been shown to exhibit excellent anti-proliferative activities in multiple cancer cell lines including DU145, JR8 and Hela cells. While AICAR is very potent in inhibiting the growth of tumor cells, it does not affect the proliferation of normal human fibroblasts. AICAR exerts its anticancer activities by inhibiting the chaperone function with destabilization of multiple Hsp90 client proteins, including survivin [59].

\section{Arctigenin (2)}

Arctigenin, a ligand isolated from the seeds of Arctium lappa, shows anti-proliferative activities against a series of cancers [60,61]. A study illustrates the mechanism of its anticancer effect [61]. The results showed that arctigenin executed its antitumor effect by inhibiting STAT3 phosphorylation and survivin expression. The level of survivin was significantly reduced in arctigenin-treated ovarian cancer cells. Arctigenin has also been shown to sensitize tumor cells to cisplatin treatment by inhibiting survivin [60].

\section{Cephalochromin (3)}

Cephalochromin, a compound isolated from the fermented broth of Cosmospora vilior YMJ89051501 [62], is used as an antibacterial agent. It has been reported that cephalochromin can inhibit cell growth and induce apoptosis in human lung cancer cells with $\mathrm{IC}_{50}$ value of $2.8 \mu \mathrm{M}$ [62]. Cephalochromin was found to exert its antitumor effect by 
downregulating several anti-apoptotic proteins, including survivin. The expression level of survivin was significantly reduced in cephalochromin-treated A549 lung cancer cells compared with untreated cells. Due to the survivin suppression effect, caspases-8, -9 , and -3 are activated, which is responsible for the induced apoptosis. The anti-proliferative effect of cephalochromin reveals the therapeutical potential of this antibacterial agent in treating cancer.

FL118 (4)

FL118 was first reported by Ling et al. in 2012 [63]. FL118 was identified through high throughput screening of compound libraries following in vitro and in vivo analysis. FL118 can inhibit cancer cell growth in a concentration of less than $1 \mathrm{nM}$. It has shown excellent antitumor activity in a series of cancer cell lines including HCT116 colon cancer cells, A549 lung cancer cells, MCF7 breast cancer cells, and PC-3 prostate cancer cells. Its antitumor activity results from inhibiting survivin promoter activity and survivin gene expression [63]. The study also demonstrated that FL118 can inhibit expression of other cancer-associated IAPs such as Mcl-1, XIAP, and cIAP2, further enhancing its anticancer activity. The in vivo studies indicated that FL118 has excellent antitumor efficacy without significant toxicity [63]. The superior anticancer activity of FL118 largely depends on its steric configuration. FL118, which has an $R$-configuration, has much better activity than its analog FL113 with an $S$-configuration. In addition, the free hydroxyl group on position 20 of FL118 is essential for activity. Esterification of the hydroxyl group on position 20 resulted in almost complete loss of activity[64]. The superior efficacy and selectivity hold significant promise for the further clinical development of FL188 and its core structure-derived analogs.

\section{Flavopiridol (5)}

Flavopiridol is a broad spectrum, cyclin-dependent kinase (CDK) inhibitor. In the study by Nathan et al., flavopiridol caused progressive loss of survivin expression by inhibiting survivin phosphorylation on Thr34 when incubated with HeLa cells [58]. Thr34 phosphorylation of survivin is a critical requirement for survivin function [65]. Sequential treatment with flavopiridol and other anticancer agents enhanced anticancer activity both in breast carcinoma MCF-7 cells and SCID/bg mice bearing MCF-7 xenograft tumors [58]. A recent study showed that flavopiridol inhibited human uterine leiomyoma growth both in vitro and in a xenograft model [66]. Flavopiridol is now in Phase II clinical trial [67, 68]. In one phase II clinical trial of flavopiridol, the combination of flavopiridol and cisplatin treatment showed clinical activity in platin resistant and sensitive ovarian/primary peritoneal cancers [68].

\section{ICG-001 (6)}

ICG-001 is a small-molecule inhibitor of $\beta$-catenin/T cell factor (TCF)-mediated transcription [69]. It has been shown that the survivin gene is mediated by TCF/ $\beta$-catenin. The treatment of SW480 and HCT116 colon cancer cells with ICG-001clearly showed the inhibition of survivin gene transcription. The survivin inhibition effect was also observed in the SW620 xenograft tumors in the ICG-001-treated group. The inhibition of survivin expression results in induction of apoptosis, which causes tumor growth inhibition. Because survivin is upregulated in most cancer cells but not in normal tissues, ICG-001 increases 
caspase activity in colon carcinoma cell lines (SW480 or HCT116) but not in normal colonic epithelial cells [69]. The specificity and strong potency of ICG-001 promise it to be a new anticancer therapeutic agent.

KPT-185 (7)

KPT-185, a selective inhibitor of nuclear export, has been shown to be effective in several cancers including pancreatic cancer, acute myeloid leukemia, mantle cell lymphoma, and nonsmall cell lung cancer (NSCLC) [70-73]. KPT-185 can significantly induce growth inhibition and apoptosis of tumor cells. A recent study showed that the survivin level is downregulated in KPT-185-treated NSCLC cell lines. The survivin level was also suppressed in an NSCLC H1975 xenografted model when treated with KPT-185 [73]. The survivin inhibition effect of KPT-185 contributes to its antitumor efficacy. Although KPT-185 has strong cytotoxicity, it is not suitable for in vivo use due to poor PK properties, while its analog KPT-330 which attaches a 2-pyrazinylhydrazinyl group to the carbonyl group and replaces the methoxy substitution on the phenyl ring with a trifluoromethyl group compared with the structure of KPT-185, has comparable potency as KPT-185 and optimal PK properties [74].

\section{Lapatinib (8)}

Lapatinib, a potent small-molecule inhibitor of ErbB1 and ErbB2 tyrosine kinases, has been shown to markedly suppress survivin expression and subsequently induce apoptosis when treated in ErbB2-overexpressing breast cancer cell lines, such as BT 474 [75]. The inhibition of survivin by lapatinib is primarily posttranslational through the promoted ubiquitinproteasome degradation of the survivin protein. The observation that the protein levels of His-tagged survivin, which are under the transcriptional control of a heterologous promoter and endogenous survivin are equally downregulated in response to lapatinib provides evidence for a posttranslational mechanism by which lapatinib regulates survivin. Lapatinib causes synergistic effects when used with other cytotoxic agents such as sorafenib [76]. Lapatinib is now in Phase 3 clinical trial [77, 78].

\section{MK-2206 (9)}

MK-2206, a novel allosteric inhibitor of Akt $[79,80]$, has strong anticancer efficacy in a series of cancer cells $[79,80]$. It has been show that Akt phosphorylation is associated with the formation of survivin/XIAP complex. Deactivating Akt phosphorylation can lead to downregulation of survivin [81]. As an Akt inhibitor, MK-2206 suppresses survivin. In a study, the level of survivin was reduced both in GEO cancer cells and GEO cell xenografted model when treated with MK-2206, which led to increased cancer cell death via apoptosis [82]. MK-2206 is now actively evaluated as a new anticancer agent and is now in Phase II clinical trial.

\section{NU6140 (10)}

NU6140, (4-(6-cyclohexylmethoxy-9Hpurin-2-ylamino)-N, N-diethyl-benzamide) is a novel CDK inhibitor developed by Davies et al. in 2002 through structure-based design [83]. Structure-activity relationships for this compound indicate that a cyclic hydrophobic 
substituent at $\mathrm{O}^{6}$-poisiton such as cyclohexylmethyl is optimal and the extended groups at $\mathrm{N}^{2}$-position increased potency and selectivity. It has been shown that CDK1-mediated phosphorylation of survivin on Thr34 is essential for the cytoprotective function of survivin [65]. As a CDK inhibitor, NU6140 induced a concentration-dependent decrease in the level of survivin protein when treated in HeLa Cells. In addition, the level of the active, Thr34phosphorylated form of survivin was reduced in a concentration-dependent manner after HeLa cells were treated with NU6140 [84]. Because the CDK inhibitor NU6140 can inhibit the expression and phosphorylation of survivin, a combination treatment of taxol and NU6140 in HeLa cells causes a synergistic effect on tumor growth inhibition.[84]

\section{Panepoxydone (11)}

Panepoxydone, a secondary metabolite isolated from an edible mushroom, has long been known for its antibacterial effect. Studies have shown that panepoxydone interferes with NF$\mathrm{kB}$, which can lead to tumor inhibition [85, 86]. Panepoxydone caused significant growth inhibition in MCF-7 and TNBC cell lines MDA-MB-231, MDA-MB-468, and MDAMB-453 [86]. The induction of apoptosis is one main factor contributing to tumor cell growth inhibition. Mechanism of action studies showed that the survivin level in the panepoxydone-treated cells was reduced, which was responsible for inducing apoptosis. The strong antitumor effect of panepoxydone promises its further development.

\section{Piperine (12)}

Piperine, an alkaloid from black pepper, inhibits the growth of several colon cancer cell lines [87]. The mechanism of action studies showed that the survivin protein levels in piperinetreated HT-29 colon carcinoma cell were reduced compared with untreated cells. The survivin inhibition effect of piperine may account for the inhibition of apoptosis and cell growth observed in piperine-treated cancer cells. Piperine can also sensitize cancer cells to other chemotherapeutical agents due to its survivin inhibition effect $[88,89]$.

\section{Purvalanol A (13)}

Purvalanol A is $\mathrm{p} 34^{\mathrm{cdc} 2}$-specific CDK inhibitor. Studies have shown that elevated $\mathrm{p} 34^{\mathrm{cdc} 2}$ kinase activity can lead to increased survivin expression [19]. Purvalanol A as a p34 $4^{\text {cdc2 }}$ specific inhibitor not only inhibits Cdc2 activity, but also suppresses survivin expression [90]. Purvalanol A can inhibit the mitotic phosphorylation of survivin on Thr34, which causes protein destruction of survivin and blockage of its function. The hyperphosphorylation of survivin on Thr34 has been found to be associated with the drug resistance of taxol in tumor cells [91]. Co-administration of taxol with purvalanol A suppressed the hyperactivity of survivin imposed by taxol, which helped overcome the taxol drug resistance [19]. Purvalanol A can also inhibit ABCB1 transporter and cause synergistic effects when used in combination with other anticancer drugs that are ABCB1 substrates [92].

\section{Shepherdin (14)}

Shepherdin, a novel antagonist of the survivin-Hsp90 complex, was discovered by Janet et al. in 2005 [93]. Shepherdin is actually the survivin sequence K79-L87 (KHSSGCAFL). It 
was named shepherdin because it binds to the "shepherding" chaperone Hsp90. Binding assay results revealed that shepherdin was bound to the $\mathrm{N}$ domain of Hsp90, while no specific binding of shepherdin to the $\mathrm{C}$ domain of Hsp90 was observed. Shepherdin disrupts the interaction between survivin and Hsp90 through the ATP binding pocket of Hsp90. Shepherdin can also destabilize survivin and several other client proteins of Hsp90, such as Akt, CDK6, and telomerase, which cause cancer cell death via apoptotic and nonapoptotic mechanisms. Shepherdin has very good selectivity, because it does not affect normal cells while maintaining excellent antitumor activity [93]. Shepherdin can sensitize tumor cells to different cytotoxic drugs because of its survivin suppression effect. For example, shepherdin sensitized imatinib mesylate-resistant chronic myelogenous leukemia cells to hydroxyurea or doxorubicin in a recent study [88]. Current clinical development is through the Rapid Access to Intervention Development (RAID) program at the National Cancer Institute.

\section{Terameprocol (15)}

Terameprocol, meso-tetra-O-methyl nordihydroguaiaretic acid, also known as M4N, has been reported to inhibit HIV transactivation [94]. Terameprocol was made based on 3'-Omethylnordihydroguaiaretic acid, which was isolated from Larrea tridentata. Subsequent studies showed that terameprocol as a transcription inhibitor can inhibit tumor growth by inhibiting expression of Cdc2 and survivin [95, 96]. In the study of Chang et al. [96], terameprocol-treated $\mathrm{C} 3$ cells showed downregulation of $\mathrm{Cdc} 2$ and survivin expression. The observation that $\mathrm{C} 3$ cells transfected with $\mathrm{Cdc} 2$ and survivin were resistant to terameprocolinduced cell arrest or death confirmed the tumor growth inhibition mechanisms of terameprocol. Terameprocol significantly enhanced the sensitivity of nonsmall-cell lung carcinoma cells to radiation therapy in the study of Sun et al [97]. Now terameprocol is in Phase I clinical trial $[98,99]$. The clinical results have shown that this agent has an excellent safety profile in cervical intraepithelial neoplasia, making it a promising candidate for anticancer treatment [98].

\section{UC112 (16)}

UC112 was recently reported by our group as a potent and selective survivin inhibitor [53]. It was identified through a similarity-based virtual screening in which the three-dimensional shape of the AVPI peptide in the survivin-Smac crystal complex was used as the template for searching hit structures, followed by biological validation. UC112 showed broad antiproliferative activities as indicated by NCI-60 cell line screening and preliminary in vivo studies in an A375 melanoma tumor model. Interestingly, preliminary studies showed that UC112 selectively downregulated survivin level with minimal effects on other members of IAPs. [53] This compound may represent a unique scaffold for the development of new selective survivin inhibitors. Further modifications of this compound are currently being carried out.

YM155 (17)

YM155, 1-(2-Methoxyethyl)-2-methyl-4, 9-dioxo-3-(pyrazin-2-ylmethyl)-4, 9-dihydro-1 $H$ naphtho [2, 3-d] imidazolium bromide, a small-molecule survivin inhibitor, was first discovered by Astellas Pharma in 2007 [57]. It suppresses survivin gene promoter in PC-3 and PPC-1 human HRPC cell lines at $10 \mathrm{nmol} / \mathrm{L}$ in cell based proliferation assay. It also 
shows very good selectivity of survivin over other IAPs. In the study of Nakahara et al., YM155 suppressed survivin expression but had little effect on the expression of other IAPs even up to $100 \mathrm{nmol} / \mathrm{L}$. YM155 induced tumor regression in PC-3 xenografted tumor model [57]. YM155 can help overcome drug resistance in tumors when used with other chemotherapeutical agents. For example, YM155 reversed rapamycin resistance in rapamycin-resistant renal cell carcinoma [100], and the combination of YM155 and cisplatin induced apoptosis and tumor regression in cisplatin-resistant ovarian cancer cells [101]. YM155 is now in Phase II clinical trial [102, 103]. Recent studies have shown that YM155 is a substrate of the P-glycoprotein [104], suggesting that it may suffer from multidrug resistance in its later clinical use.

\section{Challenges for development of survivin inhibitors}

Although survivin is a very promising target for cancer treatment and many studies have been carried out to develop survivin inhibitors, the pool of existing survivin inhibitors is still relatively small. Several problems limit the development of effective survivin inhibitors. Unlike an enzyme or a receptor molecule located on the cell surface, survivin is not a traditional target. Survivin is a nodal protein involved in multiple processes of cancer cell proliferation, including mitosis, apoptosis and autophagy. It also interferes with various molecules such as Hsp90, Borealin, INCENP, aurora B kinase and caspases. Therefore, it is a significant challenge and is very critical to unambiguously confirm that the drug action is resulted from survivin-specific inhibition. Because of such challenges, currently it is difficult to evaluate the effectiveness and target specificity of survivin inhibitors accurately via high throughput assays. The lack of suitable assays to identify survivin inhibition by high throughput screenings is one main factor to impede the development of potent and selective survivin inhibitors. Moreover, recent studies have shown that survivin exists in certain types of normal cells, mainly hematopoietic and immune systems [105]. Potential side effects will be a concern for those normal cells. Although clinical studies of survivin inhibitors to date have shown that targeting survivin does not cause toxic side effects, the prolonged use of survivin inhibitors should still be carefully studied because of the emerging role of survivin in regulating functions in normal cells.

\section{Conclusion remarks and future directions}

The results from studies in the past fifteen years provide convincing evidence that survivin is a promising target for cancer therapy treatment. As discussed in this review, survivin distinguishes itself by its unique functional properties, preferentially expressed in most human cancer cells, and involves in a myriad of cellular functions. Survivin contributes to tumor formation and progression which makes it a promising cancer drug target. Although there are significant challenges in developing effective survivin inhibitors and the number of small-molecule survivin inhibitors is still very limited, several potent survivin inhibitors have entered clinical trials, including flavopiridol, lapatinib, terameprocol, MK-2206 and YM155. Most of them have shown positive initial results, suggesting it is feasible to develop small-molecule inhibitors as efficacious anticancer drugs. Lapatinib is the most promising one among them, which is now in phase 3 clinical trials. Currently the lack of a survivinspecific assay is limiting the development of novel small-molecule survivin inhibitors. 
Developing optimized assays will greatly accelerate research in this field. In addition, further investigations of differential mechanisms regulating survivin expression and functions in tumor and normal cells will be critical to develop novel strategies for selective survivin inhibition by small molecules. Finally, it is well recognized that the efficacy of any single agent including a survivin inhibitor may be limited due to high heterogeneity and plasticity in tumor cells. Not surprisingly, the combination of survivin inhibitors and other traditional chemotherapeutical agents have been evaluated and shown enhanced clinical efficacy, indicating the inhibition of survivin can enhance the efficacy of other agents. Thus the next direction will be developing the best combinations of survivin inhibitors with other existing chemotherapeutical agents for the most efficacious strategy.

\section{List of Abbreviations}

$\begin{array}{ll}\text { AICAR } & \text { 5-aminoimidazole-4-carboxamide-1-b-D-ribofuranoside } \\ \text { BIR } & \text { baculoviral IAP repeat } \\ \text { BIRC5 } & \text { baculoviral IAP repeat-containing 5 } \\ \text { CDK } & \text { cyclin-dependent kinase } \\ \text { CPC } & \text { chromosomal passenger complex } \\ \text { HBXIP } & \text { hepatitis B X-interacting protein } \\ \text { IAP } & \text { inhibitor of apoptosis proteins } \\ \text { M4N } & \text { meso-tetra-O-methyl nordihydroguaiaretic acid } \\ \text { NAIP } & \text { NLR family, apoptosis inhibitory protein } \\ \text { NSCLC } & \text { nonsmall-cell lung cancer } \\ \text { PPI } & \text { protein-protein interaction } \\ \text { RAID } & \text { Rapid Access to Intervention Development } \\ \text { TCF } & \text { T cell factor } \\ \text { XIAP } & \text { X-linked inhibitor of apoptosis }\end{array}$

\section{References}

1. Ambrosini G, Adida C, Altieri DC. A novel anti-apoptosis gene, survivin, expressed in cancer and lymphoma. Nat Med. 1997; 3(8):917-921. [PubMed: 9256286]

2. de Almagro MC, Vucic D. The inhibitor of apoptosis (IAP) proteins are critical regulators of signaling pathways and targets for anti-cancer therapy. Exp Oncol. 2012; 34(3):200-211. [PubMed: 23070005]

3. Hunter AM, LaCasse EC, Korneluk RG. The inhibitors of apoptosis (IAPs) as cancer targets. Apoptosis. 2007; 12(9):1543-1568. [PubMed: 17573556]

4. Schimmer AD. Inhibitor of apoptosis proteins: translating basic knowledge into clinical practice. Cancer Res. 2004; 64(20):7183-7190. [PubMed: 15492230] 
5. Fulda S, Vucic D. Targeting IAP proteins for therapeutic intervention in cancer. Nat Rev Drug Discov. 2012; 11(2):109-124. [PubMed: 22293567]

6. Ryan BM, O’Donovan N, Duffy MJ. Survivin: a new target for anti-cancer therapy. Cancer Treat Rev. 2009; 35(7):553-562. [PubMed: 19559538]

7. Rauch A, Hennig D, Schafer C, Wirth M, Marx C, Heinzel T, Schneider G, Kramer OH. Survivin and YM155: how faithful is the liaison? Biochim Biophys Acta. 2014; 1845(2):202-220. [PubMed: 24440709]

8. Altieri DC. Survivin, cancer networks and pathway-directed drug discovery. Nat Rev Cancer. 2008; 8(1):61-70. [PubMed: 18075512]

9. O’Connor DS, Schechner JS, Adida C, Mesri M, Rothermel AL, Li F, Nath AK, Pober JS, Altieri DC. Control of apoptosis during angiogenesis by survivin expression in endothelial cells. Am J Pathol. 2000; 156(2):393-398. [PubMed: 10666367]

10. Waligorska-Stachura J, Jankowska A, Wasko R, Liebert W, Biczysko M, Czarnywojtek A, BaszkoBlaszyk D, Shimek V, Ruchala M. Survivin--prognostic tumor biomarker in human neoplasms-review. Ginekol Pol. 2012; 83(7):537-540. [PubMed: 22880480]

11. Kawasaki H, Toyoda M, Shinohara H, Okuda J, Watanabe I, Yamamoto T, Tanaka K, Tenjo T, Tanigawa N. Expression of survivin correlates with apoptosis, proliferation, and angiogenesis during human colorectal tumorigenesis. Cancer. 2001; 91(11):2026-2032. [PubMed: 11391581]

12. Mita AC, Mita MM, Nawrocki ST, Giles FJ. Survivin: key regulator of mitosis and apoptosis and novel target for cancer therapeutics. Clin Cancer Res. 2008; 14(16):5000-5005. [PubMed: 18698017]

13. Cheung CH, Huang CC, Tsai FY, Lee JY, Cheng SM, Chang YC, Huang YC, Chen SH, Chang JY. Survivin - biology and potential as a therapeutic target in oncology. Onco Targets Ther. 2013; 6:1453-1462. [PubMed: 24204160]

14. Yang D, Welm A, Bishop JM. Cell division and cell survival in the absence of survivin. Proc Natl Acad Sci U S A. 2004; 101(42):15100-15105. [PubMed: 15477601]

15. Vader G, Kauw JJ, Medema RH, Lens SM. Survivin mediates targeting of the chromosomal passenger complex to the centromere and midbody. EMBO Rep. 2006; 7(1):85-92. [PubMed: 16239925]

16. Ruchaud S, Carmena M, Earnshaw WC. The chromosomal passenger complex: one for all and all for one. Cell. 2007; 131(2):230-231. [PubMed: 17956723]

17. Ruchaud S, Carmena M, Earnshaw WC. Chromosomal passengers: conducting cell division. Nat Rev Mol Cell Biol. 2007; 8(10):798-812. [PubMed: 17848966]

18. Wiedemuth R, Klink B, Topfer K, Schrock E, Schackert G, Tatsuka M, Temme A. Survivin safeguards chromosome numbers and protects from aneuploidy independently from $\mathrm{p} 53$. Mol Cancer. 2014; 13:107. [PubMed: 24886358]

19. O'Connor DS, Wall NR, Porter AC, Altieri DC. A p34(cdc2) survival checkpoint in cancer. Cancer Cell. 2002; 2(1):43-54. [PubMed: 12150824]

20. Giodini A, Kallio MJ, Wall NR, Gorbsky GJ, Tognin S, Marchisio PC, Symons M, Altieri DC. Regulation of microtubule stability and mitotic progression by survivin. Cancer Res. 2002; 62(9): 2462-2467. [PubMed: 11980633]

21. Altieri DC. The case for survivin as a regulator of microtubule dynamics and cell-death decisions. Curr Opin Cell Biol. 2006; 18(6):609-615. [PubMed: 16934447]

22. Tamm I, Wang Y, Sausville E, Scudiero DA, Vigna N, Oltersdorf T, Reed JC. IAP-family protein survivin inhibits caspase activity and apoptosis induced by Fas (CD95), Bax, caspases, and anticancer drugs. Cancer Res. 1998; 58(23):5315-5320. [PubMed: 9850056]

23. Shin S, Sung BJ, Cho YS, Kim HJ, Ha NC, Hwang JI, Chung CW, Jung YK, Oh BH. An antiapoptotic protein human survivin is a direct inhibitor of caspase-3 and -7. Biochemistry. 2001; 40(4):1117-1123. [PubMed: 11170436]

24. Grossman D, Kim PJ, Blanc-Brude OP, Brash DE, Tognin S, Marchisio PC, Altieri DC. Transgenic expression of survivin in keratinocytes counteracts UVB-induced apoptosis and cooperates with loss of p53. J Clin Invest. 2001; 108(7):991-999. [PubMed: 11581300]

25. Yamamoto T, Manome Y, Nakamura M, Tanigawa N. Downregulation of survivin expression by induction of the effector cell protease receptor-1 reduces tumor growth potential and results in an 
increased sensitivity to anticancer agents in human colon cancer. Eur J Cancer. 2002; 38(17):23162324. [PubMed: 12441269]

26. Dohi T, Okada K, Xia F, Wilford CE, Samuel T, Welsh K, Marusawa H, Zou H, Armstrong R, Matsuzawa S, Salvesen GS, Reed JC, Altieri DC. An IAP-IAP complex inhibits apoptosis. J Biol Chem. 2004; 279(33):34087-34090. [PubMed: 15218035]

27. Hu D, Liu S, Shi L, Li C, Wu L, Fan Z. Cleavage of survivin by Granzyme M triggers degradation of the survivin-X-linked inhibitor of apoptosis protein (XIAP) complex to free caspase activity leading to cytolysis of target tumor cells. J Biol Chem. 2010; 285(24):18326-18335. [PubMed: 20406824]

28. Marusawa H, Matsuzawa S, Welsh K, Zou H, Armstrong R, Tamm I, Reed JC. HBXIP functions as a cofactor of survivin in apoptosis suppression. EMBO J. 2003; 22(11):2729-2740. [PubMed: 12773388]

29. Duffy MJ, O’Donovan N, Brennan DJ, Gallagher WM, Ryan BM. Survivin: a promising tumor biomarker. Cancer Lett. 2007; 249(1):49-60. [PubMed: 17275177]

30. Li Y, Ma X, Wu X, Liu X, Liu L. Prognostic Significance of Survivin in Breast Cancer: Metaanalysis. Breast J. 2014

31. Lv S, Dai C, Liu Y, Shi R, Tang Z, Han M, Bian R, Sun B, Wang R. The Impact of Survivin on Prognosis and Clinicopathology of Glioma Patients: A Systematic Meta-Analysis. Mol Neurobiol. 2014

32. Monzo M, Rosell R, Felip E, Astudillo J, Sanchez JJ, Maestre J, Martin C, Font A, Barnadas A, Abad A. A novel anti-apoptosis gene: Re-expression of survivin messenger RNA as a prognosis marker in non-small-cell lung cancers. J Clin Oncol. 1999; 17(7):2100-2104. [PubMed: 10561264]

33. Tanaka K, Iwamoto S, Gon G, Nohara T, Iwamoto M, Tanigawa N. Expression of survivin and its relationship to loss of apoptosis in breast carcinomas. Clin Cancer Res. 2000; 6(1):127-134. [PubMed: 10656440]

34. Satoh K, Kaneko K, Hirota M, Masamune A, Satoh A, Shimosegawa T. Tumor necrosis factorrelated apoptosis-inducing ligand and its receptor expression and the pathway of apoptosis in human pancreatic cancer. Pancreas. 2001; 23(3):251-258. [PubMed: 11590320]

35. Grossman D, McNiff JM, Li F, Altieri DC. Expression and targeting of the apoptosis inhibitor, survivin, in human melanoma. J Invest Dermatol. 1999; 113(6):1076-1081. [PubMed: 10594755]

36. Cheung CH, Sun X, Kanwar JR, Bai JZ, Cheng L, Krissansen GW. A cell-permeable dominantnegative survivin protein induces apoptosis and sensitizes prostate cancer cells to TNF-alpha therapy. Cancer Cell Int. 2010; 10:36. [PubMed: 20920299]

37. Ling X, Calinski D, Chanan-Khan AA, Zhou M, Li F. Cancer cell sensitivity to bortezomib is associated with survivin expression and p53 status but not cancer cell types. J Exp Clin Cancer Res. 2010; 29:8. [PubMed: 20096120]

38. He SQ, Rehman H, Gong MG, Zhao YZ, Huang ZY, Li CH, Zhang WG, Chen XP. Inhibiting survivin expression enhances TRAIL-induced tumoricidal activity in human hepatocellular carcinoma via cell cycle arrest. Cancer Biol Ther. 2007; 6(8):1247-1257. [PubMed: 17700059]

39. Moriai R, Tsuji N, Moriai M, Kobayashi D, Watanabe N. Survivin plays as a resistant factor against tamoxifen-induced apoptosis in human breast cancer cells. Breast Cancer Res Treat. 2009; 117(2):261-271. [PubMed: 18815881]

40. Nomura T, Yamasaki M, Nomura Y, Mimata H. Expression of the inhibitors of apoptosis proteins in cisplatin-resistant prostate cancer cells. Oncol Rep. 2005; 14(4):993-997. [PubMed: 16142363]

41. Tirro E, Consoli ML, Massimino M, Manzella L, Frasca F, Sciacca L, Vicari L, Stassi G, Messina L, Messina A, Vigneri P. Altered expression of c-IAP1, survivin, and Smac contributes to chemotherapy resistance in thyroid cancer cells. Cancer Res. 2006; 66(8):4263-4272. [PubMed: 16618750]

42. Adisetiyo H, Liang M, Liao CP, Aycock-Williams A, Cohen MB, Xu S, Neamati N, Conway EM, Cheng CY, Nikitin AY, Roy-Burman P. Loss of survivin in the prostate epithelium impedes carcinogenesis in a mouse model of prostate adenocarcinoma. PLoS One. 2013; 8(7):e69484. [PubMed: 23936028] 
43. Mobahat M, Narendran A, Riabowol K. Survivin as a preferential target for cancer therapy. Int J Mol Sci. 2014; 15(2):2494-2516. [PubMed: 24531137]

44. Athanasoula K, Gogas H, Polonifi K, Vaiopoulos AG, Polyzos A, Mantzourani M. Survivin beyond physiology: orchestration of multistep carcinogenesis and therapeutic potentials. Cancer Lett. 2014; 347(2):175-182. [PubMed: 24560928]

45. Ghanbari P, Mohseni M, Tabasinezhad M, Yousefi B, Saei AA, Sharifi S, Rashidi MR, Samadi N. Inhibition of Survivin Restores the Sensitivity of Breast Cancer Cells to Docetaxel and Vinblastine. Appl Biochem Biotechnol. 2014

46. Wang R, Chen DQ, Huang JY, Zhang K, Feng B, Pan BZ, Chen J, De W, Chen LB. Acquisition of radioresistance in docetaxel-resistant human lung adenocarcinoma cells is linked with dysregulation of miR-451/c-Myc-survivin/rad-51 signaling. Oncotarget. 2014

47. Sun XP, Dong X, Lin L, Jiang X, Wei Z, Zhai B, Sun B, Zhang Q, Wang X, Jiang H, Krissansen GW, Qiao H, Sun X. Up-regulation of survivin by AKT and hypoxia-inducible factor 1alpha contributes to cisplatin resistance in gastric cancer. FEBS J. 2014; 281(1):115-128. [PubMed: 24165223]

48. Buchwald P. Small-molecule protein-protein interaction inhibitors: therapeutic potential in light of molecular size, chemical space, and ligand binding efficiency considerations. IUBMB Life. 2010; 62(10):724-731. [PubMed: 20979208]

49. Fuller JC, Burgoyne NJ, Jackson RM. Predicting druggable binding sites at the protein-protein interface. Drug Discov Today. 2009; 14(3-4):155-161. [PubMed: 19041415]

50. Wishart DS, Knox C, Guo AC, Cheng D, Shrivastava S, Tzur D, Gautam B, Hassanali M. DrugBank: a knowledgebase for drugs, drug actions and drug targets. Nucleic Acids Res. 2008; 36(Database issue):D901-906. [PubMed: 18048412]

51. Lagane B, Garcia-Perez J, Kellenberger E. Modeling the allosteric modulation of CCR5 function by Maraviroc. Drug Discov Today Technol. 2013; 10(2):e297-305. [PubMed: 24050281]

52. Bogan AA, Thorn KS. Anatomy of hot spots in protein interfaces. J Mol Biol. 1998; 280(1):1-9. [PubMed: 9653027]

53. Wang J, Li W. Discovery of novel second mitochondria-derived activator of caspase mimetics as selective inhibitor of apoptosis protein inhibitors. J Pharmacol Exp Ther. 2014; 349(2):319-329. [PubMed: 24623800]

54. Du J, Kelly AE, Funabiki H, Patel DJ. Structural basis for recognition of H3T3ph and Smac/ DIABLO N-terminal peptides by human Survivin. Structure. 2012; 20(1):185-195. [PubMed: 22244766]

55. Pennati M, Folini M, Zaffaroni N. Targeting survivin in cancer therapy: fulfilled promises and open questions. Carcinogenesis. 2007; 28(6):1133-1139. [PubMed: 17341657]

56. Coumar MS, Tsai FY, Kanwar JR, Sarvagalla S, Cheung CH. Treat cancers by targeting survivin: just a dream or future reality? Cancer Treat Rev. 2013; 39(7):802-811. [PubMed: 23453862]

57. Nakahara T, Kita A, Yamanaka K, Mori M, Amino N, Takeuchi M, Tominaga F, Hatakeyama S, Kinoyama I, Matsuhisa A, Kudoh M, Sasamata M. YM155, a novel small-molecule survivin suppressant, induces regression of established human hormone-refractory prostate tumor xenografts. Cancer Res. 2007; 67(17):8014-8021. [PubMed: 17804712]

58. Wall NR, O’Connor DS, Plescia J, Pommier Y, Altieri DC. Suppression of survivin phosphorylation on Thr34 by flavopiridol enhances tumor cell apoptosis. Cancer Res. 2003; 63(1): 230-235. [PubMed: 12517802]

59. Meli M, Pennati M, Curto M, Daidone MG, Plescia J, Toba S, Altieri DC, Zaffaroni N, Colombo G. Small-molecule targeting of heat shock protein 90 chaperone function: rational identification of a new anticancer lead. J Med Chem. 2006; 49(26):7721-7730. [PubMed: 17181154]

60. Wang HQ, Jin JJ, Wang J. Arctigenin enhances chemosensitivity to cisplatin in human nonsmall lung cancer H460 cells through downregulation of survivin expression. J Biochem Mol Toxicol. 2014; 28(1):39-45. [PubMed: 24395429]

61. Huang K, Li LA, Meng YG, You YQ, Fu XY, Song L. Arctigenin Promotes Apoptosis in Ovarian Cancer Cells via the iNOS/NO/STAT3/Survivin Signalling. Basic Clin Pharmacol Toxicol. 2014

62. Hsiao CJ, Hsiao G, Chen WL, Wang SW, Chiang CP, Liu LY, Guh JH, Lee TH, Chung CL. Cephalochromin induces G0/G1 cell cycle arrest and apoptosis in A549 human non-small-cell 
lung cancer cells by inflicting mitochondrial disruption. J Nat Prod. 2014; 77(4):758-765. [PubMed: 24588135]

63. Ling X, Cao S, Cheng Q, Keefe JT, Rustum YM, Li F. A novel small molecule FL118 that selectively inhibits survivin, Mcl-1, XIAP and cIAP2 in a p53-independent manner, shows superior antitumor activity. PLoS One. 2012; 7(9):e45571. [PubMed: 23029106]

64. Zhao J, Ling X, Cao S, Liu X, Wan S, Jiang T, Li F. Antitumor activity of FL118, a survivin, Mcl-1, XIAP, and cIAP2 selective inhibitor, is highly dependent on its primary structure and steric configuration. Mol Pharm. 2014; 11(2):457-467. [PubMed: 24329001]

65. O’Connor DS, Grossman D, Plescia J, Li F, Zhang H, Villa A, Tognin S, Marchisio PC, Altieri DC. Regulation of apoptosis at cell division by p34cdc2 phosphorylation of survivin. Proc Natl Acad Sci U S A. 2000; 97(24):13103-13107. [PubMed: 11069302]

66. Lee HG, Baek JW, Shin SJ, Kwon SH, Cha SD, Park WJ, Chung R, Choi ES, Lee GH, Cho CH. Antitumor Effects of Flavopiridol on Human Uterine Leiomyoma In Vitro and in a Xenograft model. Reprod Sci. 2014

67. Karp JE, Garrett-Mayer E, Estey EH, Rudek MA, Smith BD, Greer JM, Drye DM, Mackey K, Dorcy KS, Gore SD, Levis MJ, McDevitt MA, Carraway HE, Pratz KW, Gladstone DE, Showel MM, Othus M, Doyle LA, Wright JJ, Pagel JM. Randomized phase II study of two schedules of flavopiridol given as timed sequential therapy with cytosine arabinoside and mitoxantrone for adults with newly diagnosed, poor-risk acute myelogenous leukemia. Haematologica. 2012; 97(11):1736-1742. [PubMed: 22733022]

68. Bible KC, Peethambaram PP, Oberg AL, Maples W, Groteluschen DL, Boente M, Burton JK, Gomez Dahl LC, Tibodeau JD, Isham CR, Maguire JL, Shridhar V, Kukla AK, Voll KJ, Mauer MJ, Colevas AD, Wright J, Doyle LA, Erlichman C, Mayo Phase C. North Central Cancer Treatment G. A phase 2 trial of flavopiridol (Alvocidib) and cisplatin in platin-resistant ovarian and primary peritoneal carcinoma: MC0261. Gynecol Oncol. 2012; 127(1):55-62. [PubMed: 22664059]

69. Emami KH, Nguyen C, Ma H, Kim DH, Jeong KW, Eguchi M, Moon RT, Teo JL, Kim HY, Moon SH, Ha JR, Kahn M. A small molecule inhibitor of beta-catenin/CREB-binding protein transcription [corrected]. Proc Natl Acad Sci U S A. 2004; 101(34):12682-12687. [PubMed: 15314234]

70. Azmi AS, Aboukameel A, Bao B, Sarkar FH, Philip PA, Kauffman M, Shacham S, Mohammad RM. Selective inhibitors of nuclear export block pancreatic cancer cell proliferation and reduce tumor growth in mice. Gastroenterology. 2013; 144(2):447-456. [PubMed: 23089203]

71. Etchin J, Sun Q, Kentsis A, Farmer A, Zhang ZC, Sanda T, Mansour MR, Barcelo C, McCauley D, Kauffman M, Shacham S, Christie AL, Kung AL, Rodig SJ, Chook YM, Look AT. Antileukemic activity of nuclear export inhibitors that spare normal hematopoietic cells. Leukemia. 2013; 27(1): 66-74. [PubMed: 22847027]

72. Zhang K, Wang M, Tamayo AT, Shacham S, Kauffman M, Lee J, Zhang L, Ou Z, Li C, Sun L, Ford RJ, Pham LV. Novel selective inhibitors of nuclear export CRM1 antagonists for therapy in mantle cell lymphoma. Exp Hematol. 2013; 41(1):67-78. e64. [PubMed: 22986101]

73. Wang S, Han X, Wang J, Yao J, Shi Y. Antitumor effects of a novel chromosome region maintenance 1 (CRM1) inhibitor on non-small cell lung cancer cells in vitro and in mouse tumor xenografts. PLoS One. 2014; 9(3):e89848. [PubMed: 24595136]

74. Tai YT, Landesman Y, Acharya C, Calle Y, Zhong MY, Cea M, Tannenbaum D, Cagnetta A, Reagan M, Munshi AA, Senapedis W, Saint-Martin JR, Kashyap T, Shacham S, Kauffman M, Gu Y, Wu L, Ghobrial I, Zhan F, Kung AL, Schey SA, Richardson P, Munshi NC, Anderson KC. CRM1 inhibition induces tumor cell cytotoxicity and impairs osteoclastogenesis in multiple myeloma: molecular mechanisms and therapeutic implications. Leukemia. 2014; 28(1):155-165. [PubMed: 23588715]

75. Xia W, Bisi J, Strum J, Liu L, Carrick K, Graham KM, Treece AL, Hardwicke MA, Dush M, Liao Q, Westlund RE, Zhao S, Bacus S, Spector NL. Regulation of survivin by ErbB2 signaling: therapeutic implications for ErbB2-overexpressing breast cancers. Cancer Res. 2006; 66(3):16401647. [PubMed: 16452223] 
76. Kacan T, Altun A, Altun GG, Kacan SB, Sarac B, Seker MM, Bahceci A, Babacan N. Investigation of antitumor effects of sorafenib and lapatinib alone and in combination on MCF-7 breast cancer cells. Asian Pac J Cancer Prev. 2014; 15(7):3185-3189. [PubMed: 24815468]

77. Robidoux A, Tang G, Rastogi P, Geyer CE Jr, Azar CA, Atkins JN, Fehrenbacher L, Bear HD, Baez-Diaz L, Sarwar S, Margolese RG, Farrar WB, Brufsky AM, Shibata HR, Bandos H, Paik S, Costantino JP, Swain SM, Mamounas EP, Wolmark N. Lapatinib as a component of neoadjuvant therapy for HER2-positive operable breast cancer (NSABP protocol B-41): an open-label randomised phase 3 trial. Lancet Oncol. 2013; 14(12):1183-1192. [PubMed: 24095300]

78. Baselga J, Bradbury I, Eidtmann H, Di Cosimo S, de Azambuja E, Aura C, Gomez H, Dinh P, Fauria K, Van Dooren V, Aktan G, Goldhirsch A, Chang TW, Horvath Z, Coccia-Portugal M, Domont J, Tseng LM, Kunz G, Sohn JH, Semiglazov V, Lerzo G, Palacova M, Probachai V, Pusztai L, Untch M, Gelber RD, Piccart-Gebhart M, Neo AST. Lapatinib with trastuzumab for HER2-positive early breast cancer (NeoALTTO): a randomised, open-label, multicentre, phase 3 trial. Lancet. 2012; 379(9816):633-640. [PubMed: 22257673]

79. Cheng Y, Zhang Y, Zhang L, Ren X, Huber-Keener KJ, Liu X, Zhou L, Liao J, Keihack H, Yan L, Rubin E, Yang JM. MK-2206, a novel allosteric inhibitor of Akt, synergizes with gefitinib against malignant glioma via modulating both autophagy and apoptosis. Mol Cancer Ther. 2012; 11(1): 154-164. [PubMed: 22057914]

80. Liu R, Liu D, Xing M. The Akt inhibitor MK2206 synergizes, but perifosine antagonizes, the BRAF(V600E) inhibitor PLX4032 and the MEK1/2 inhibitor AZD6244 in the inhibition of thyroid cancer cells. J Clin Endocrinol Metab. 2012; 97(2):E173-182. [PubMed: 22090271]

81. Chowdhury S, Howell GM, Rajput A, Teggart CA, Brattain LE, Weber HR, Chowdhury A, Brattain MG. Identification of a novel TGFbeta/PKA signaling transduceome in mediating control of cell survival and metastasis in colon cancer. PLoS One. 2011; 6(5):e19335. [PubMed: 21559296]

82. Agarwal E, Chaudhuri A, Leiphrakpam PD, Haferbier KL, Brattain MG, Chowdhury S. Akt inhibitor MK-2206 promotes anti-tumor activity and cell death by modulation of AIF and Ezrin in colorectal cancer. BMC Cancer. 2014; 14:145. [PubMed: 24581231]

83. Davies TG, Bentley J, Arris CE, Boyle FT, Curtin NJ, Endicott JA, Gibson AE, Golding BT, Griffin RJ, Hardcastle IR, Jewsbury P, Johnson LN, Mesguiche V, Newell DR, Noble ME, Tucker JA, Wang L, Whitfield HJ. Structure-based design of a potent purine-based cyclin-dependent kinase inhibitor. Nat Struct Biol. 2002; 9(10):745-749. [PubMed: 12244298]

84. Pennati M, Campbell AJ, Curto M, Binda M, Cheng Y, Wang LZ, Curtin N, Golding BT, Griffin RJ, Hardcastle IR, Henderson A, Zaffaroni N, Newell DR. Potentiation of paclitaxel-induced apoptosis by the novel cyclin-dependent kinase inhibitor NU6140: a possible role for survivin down-regulation. Mol Cancer Ther. 2005; 4(9):1328-1337. [PubMed: 16170024]

85. Erkel G, Anke T, Sterner O. Inhibition of NF-kappa B activation by panepoxydone. Biochem Biophys Res Commun. 1996; 226(1):214-221. [PubMed: 8806616]

86. Arora R, Yates C, Gary BD, McClellan S, Tan M, Xi Y, Reed E, Piazza GA, Owen LB, DeanColomb W. Panepoxydone targets NF-kB and FOXM1 to inhibit proliferation, induce apoptosis and reverse epithelial to mesenchymal transition in breast cancer. PLoS One. 2014; 9(6):e98370. [PubMed: 24896091]

87. Yaffe PB, Power Coombs MR, Doucette CD, Walsh M, Hoskin DW. Piperine, an alkaloid from black pepper, inhibits growth of human colon cancer cells via G1 arrest and apoptosis triggered by endoplasmic reticulum stress. Mol Carcinog. 2014

88. Stella S, Tirro E, Conte E, Stagno F, Di Raimondo F, Manzella L, Vigneri P. Suppression of survivin induced by a BCR-ABL/JAK2/STAT3 pathway sensitizes imatinib-resistant CML cells to different cytotoxic drugs. Mol Cancer Ther. 2013; 12(6):1085-1098. [PubMed: 23536723]

89. Abdelhamed S, Yokoyama S, Refaat A, Ogura K, Yagita H, Awale S, Saiki I. Piperine enhances the efficacy of TRAIL-based therapy for triple-negative breast cancer cells. Anticancer Res. 2014; 34(4):1893-1899. [PubMed: 24692724]

90. Iizuka D, Ogura A, Kuwabara M, Inanami O. Purvalanol A induces apoptosis and downregulation of antiapoptotic proteins through abrogation of phosphorylation of JAK2/STAT3 and RNA polymerase II. Anticancer Drugs. 2008; 19(6):565-572. [PubMed: 18525315] 
91. Zaffaroni N, Pennati M, Colella G, Perego P, Supino R, Gatti L, Pilotti S, Zunino F, Daidone MG. Expression of the anti-apoptotic gene survivin correlates with taxol resistance in human ovarian cancer. Cell Mol Life Sci. 2002; 59(8):1406-1412. [PubMed: 12363043]

92. Cihalova D, Hofman J, Ceckova M, Staud F. Purvalanol A, olomoucine II and roscovitine inhibit ABCB1 transporter and synergistically potentiate cytotoxic effects of daunorubicin in vitro. PLoS One. 2013; 8(12):e83467. [PubMed: 24376706]

93. Plescia J, Salz W, Xia F, Pennati M, Zaffaroni N, Daidone MG, Meli M, Dohi T, Fortugno P, Nefedova Y, Gabrilovich DI, Colombo G, Altieri DC. Rational design of shepherdin, a novel anticancer agent. Cancer Cell. 2005; 7(5):457-468. [PubMed: 15894266]

94. Hwu JR, Tseng WN, Gnabre J, Giza P, Huang RC. Antiviral activities of methylated nordihydroguaiaretic acids. 1. Synthesis, structure identification, and inhibition of tat-regulated HIV transactivation. J Med Chem. 1998; 41(16):2994-3000. [PubMed: 9685238]

95. Heller JD, Kuo J, Wu TC, Kast WM, Huang RC. Tetra-O-methyl nordihydroguaiaretic acid induces G2 arrest in mammalian cells and exhibits tumoricidal activity in vivo. Cancer Res. 2001; 61(14):5499-5504. [PubMed: 11454698]

96. Chang CC, Heller JD, Kuo J, Huang RC. Tetra-O-methyl nordihydroguaiaretic acid induces growth arrest and cellular apoptosis by inhibiting Cdc2 and survivin expression. Proc Natl Acad Sci U S A. 2004; 101(36):13239-13244. [PubMed: 15329416]

97. Sun Y, Giacalone NJ, Lu B. Terameprocol (tetra-O-methyl nordihydroguaiaretic acid): an inhibitor of Sp1-mediated survivin transcription, induces radiosensitization in non-small cell lung carcinoma. J Thorac Oncol. 2011; 6(1):8-14. [PubMed: 21107289]

98. Khanna N, Dalby R, Tan M, Arnold S, Stern J, Frazer N. Phase I/II clinical safety studies of terameprocol vaginal ointment. Gynecol Oncol. 2007; 107(3):554-562. [PubMed: 17905420]

99. Grossman SA, Ye X, Peereboom D, Rosenfeld MR, Mikkelsen T, Supko JG, Desideri S. Adult Brain Tumor C. Phase I study of terameprocol in patients with recurrent high-grade glioma. Neuro Oncol. 2012; 14(4):511-517. [PubMed: 22323663]

100. Koike H, Nitta T, Sekine Y, Arai S, Furuya Y, Nomura M, Matsui H, Shibata Y, Ito K, Oyama T, Suzuki K. YM155 reverses rapamycin resistance in renal cancer by decreasing survivin. J Cancer Res Clin Oncol. 2014

101. Mir R, Stanzani E, Martinez-Soler F, Villanueva A, Vidal A, Condom E, Ponce J, Gil J, Tortosa A, Gimenez-Bonafe P. YM155 sensitizes ovarian cancer cells to cisplatin inducing apoptosis and tumor regression. Gynecol Oncol. 2014; 132(1):211-220. [PubMed: 24262875]

102. Cheson BD, Bartlett NL, Vose JM, Lopez-Hernandez A, Seiz AL, Keating AT, Shamsili S, Papadopoulos KP. A phase II study of the survivin suppressant YM155 in patients with refractory diffuse large B-cell lymphoma. Cancer. 2012; 118(12):3128-3134. [PubMed: 22006123]

103. Giaccone G, Zatloukal P, Roubec J, Floor K, Musil J, Kuta M, van Klaveren RJ, Chaudhary S, Gunther A, Shamsili S. Multicenter phase II trial of YM155, a small-molecule suppressor of survivin, in patients with advanced, refractory, non-small-cell lung cancer. J Clin Oncol. 2009; 27(27):4481-4486. [PubMed: 19687333]

104. Iwai M, Minematsu T, Li Q, Iwatsubo T, Usui T. Utility of P-glycoprotein and organic cation transporter 1 double-transfected LLC-PK1 cells for studying the interaction of YM155 monobromide, novel small-molecule survivin suppressant, with P-glycoprotein. Drug Metab Dispos. 2011; 39(12):2314-2320. [PubMed: 21918035]

105. Fukuda S, Pelus LM. Survivin, a cancer target with an emerging role in normal adult tissues. Mol Cancer Ther. 2006; 5(5):1087-1098. [PubMed: 16731740] 


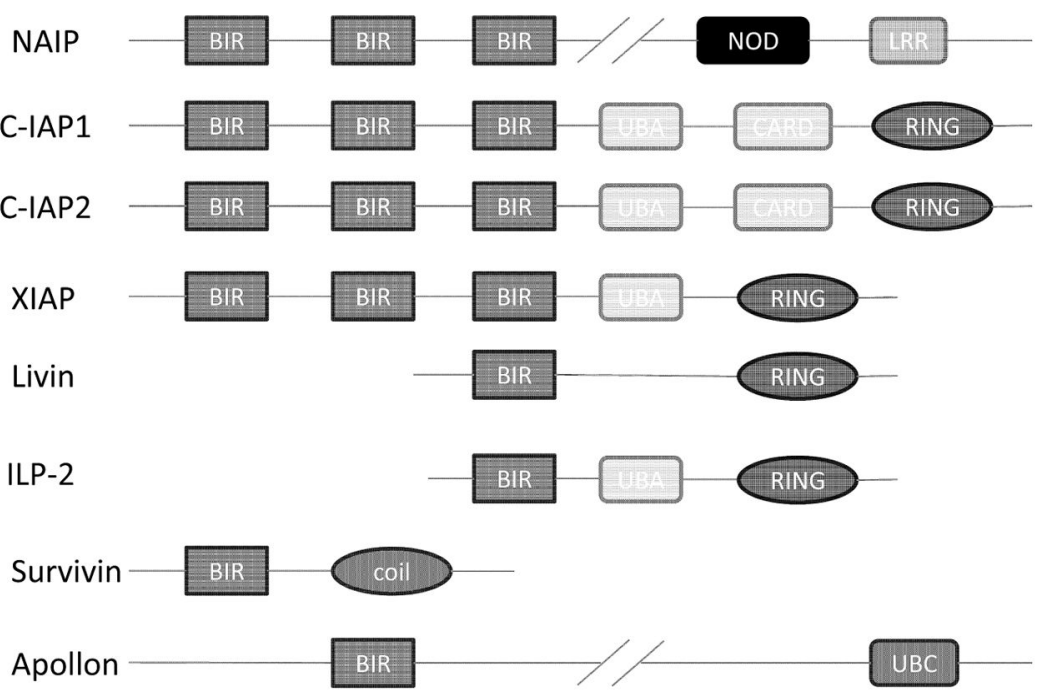

BIR: Baculoviral IAP repeat

NOD: Nucleotide binding and oligomerization domain

LRR: Leucine rich repeat

CARD: Caspase recruitment domain

UBA: Ubiquitin associated domain

RING: Really interesting new gene coil: Coiled-coil

UBC: Ubiquitin conjugating domain

Figure 1.

Schematic diagram of human IAPs 

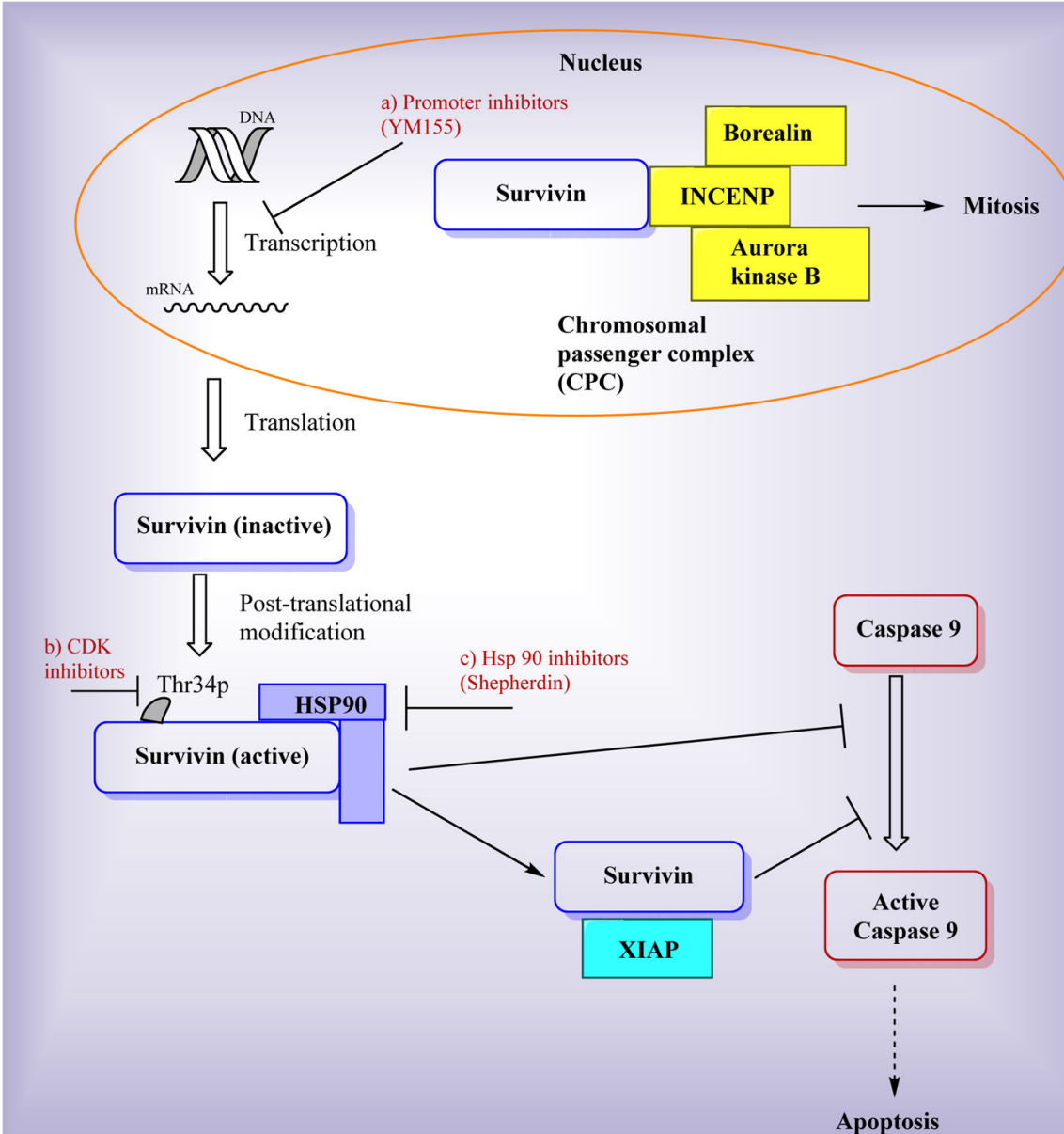

Figure 2.

Functions of survivin and targets of survivin inhibitors 

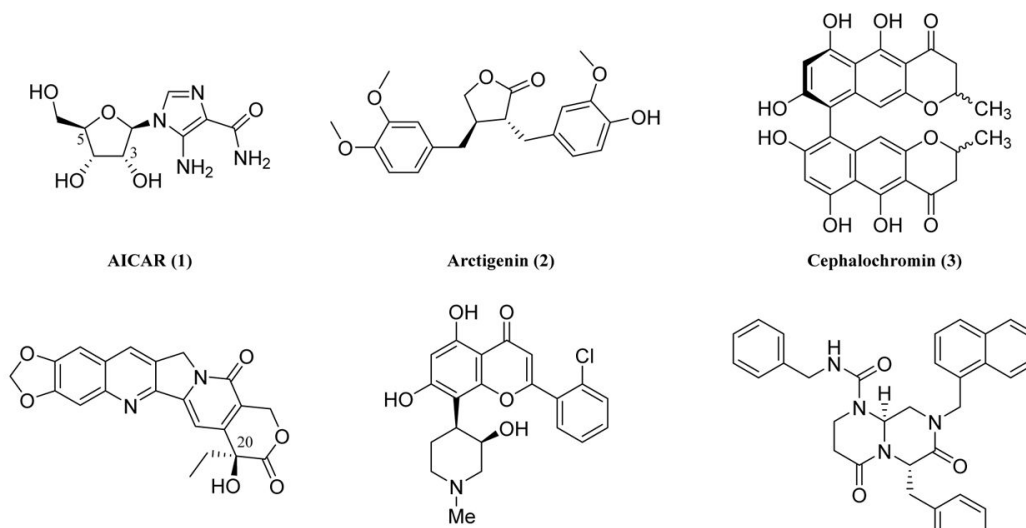

Cephalochromin (3)

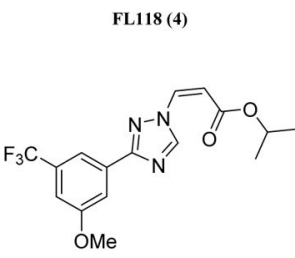

Flavopiridol (5)
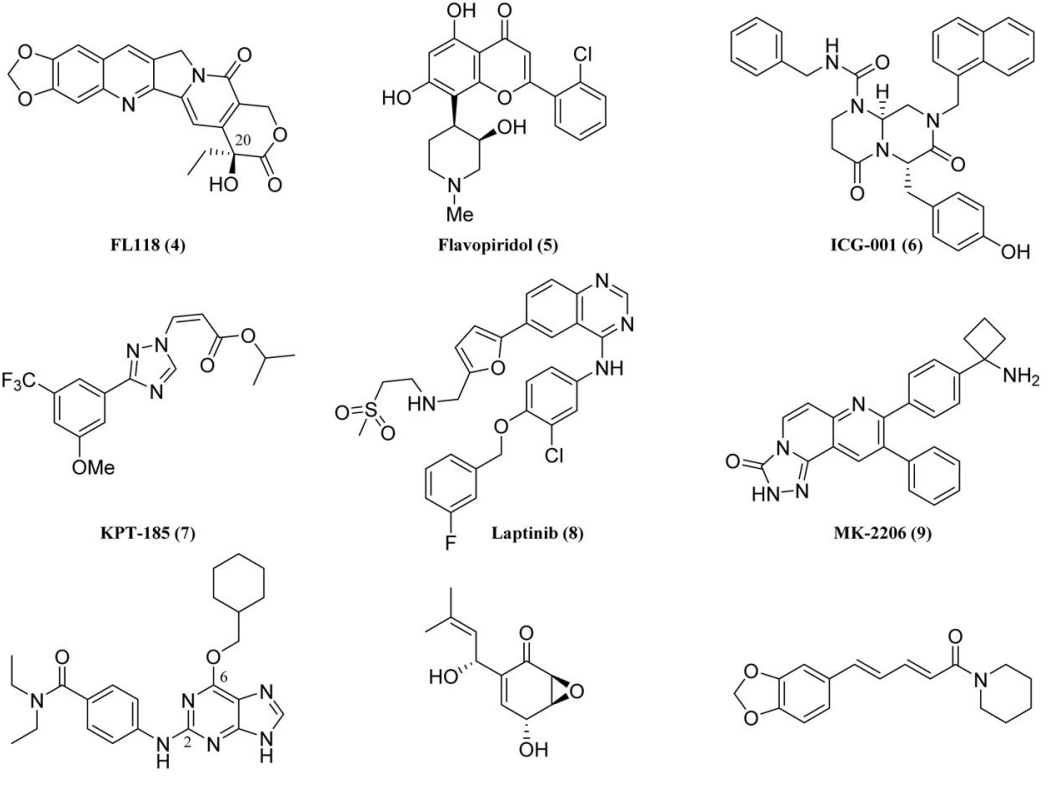

NU6140 (10)

Panepoxydone (11)
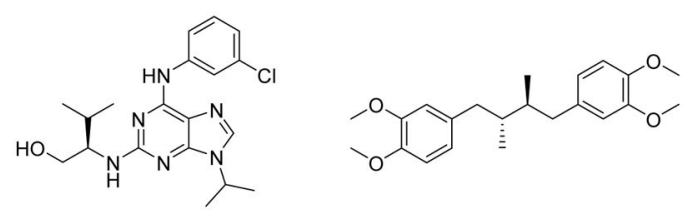

Piperine (12)

Purvalanol A (13)

Terameprocol (15)

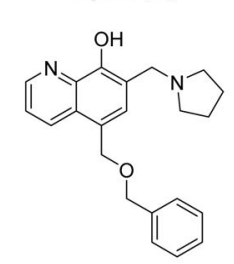

UC112 (16)

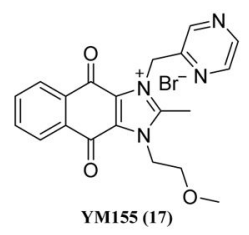

Figure 3.

Chemical structures of recently developed small-molecule survivin inhibitors. 